\title{
Economics Of Freedom: An Empirical Analysis
}

Reza G. Hamzaee, Missouri Western State University \& Walden University

G. Rod Erfani, Transylvania University

\begin{abstract}
Human freedom, and therefore, quality of life in many countries of the world have been restricted and diminished. Economic freedom and a controversial issue of interrelationship between economic and political freedom are empirically examined here. In several empirical estimations, embodying 155 countries of the world, some tight as well as statistically significant relationships are detected between economic freedom, on the one hand, and civil liberties, political rights, and political freedom, on the other.
\end{abstract}

Keywords: Economic freedom; political rights, civil rights, economic prosperity

\section{INTRODUCTION}

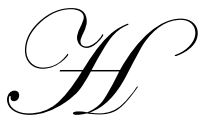

uman freedom in many countries of the world has been restricted and diminished leading to a loss in quality of life for millions (Human Rights Watch, 2006). Does this lack of freedom affect a nation economically? The authors have tested a large number of sovereign nations to see whether there is any statistically significant relationship between political democracy and economic prosperity. In other words, at a global level, is it the case that the freedoms afforded to citizens by political democracy breed economic stability and growth?

Human freedom, and therefore, quality of life in many countries of the world have been restricted and diminished. Among other issues addressed here, are the following three main research questions:

1. Considering a large number of sovereign nations, is there any statistically significant relationship between political democracy and economic prosperity?

2. What is the overall world's picture of promotion of either political or economic democracy in isolation of one from the other?

3. What is the actual status of globalization, as applied to a country like Iran?

While a review of the related literature is presented in the next section, a theoretical model, including structural equations for regression estimation, is proposed for empirical examination and analysis. Also, the corresponding data are compiled from the international and Iranian sources, including the World Bank, United Nations, Iranian Central Bank, Iran Economics, the London Economist, Heritage Foundation (2006), Freedom House (2006), Oxford University, and International Financial Statistics, etc.

Variables, such as economic freedom, political rights, civil liberties, and political freedom (political rights and civil liberties) will be all studied, analyzed, ranked for many nations in the world, and incorporated into the model for the empirical analysis.

\section{LITERATURE REVIEW}

Various researchers' views vary on whether political democracy affects economic growth and how. Those who believe the connection exists do not agree on whether it is a positive or negative correlation. What then is the 
major question to be answered here? The differences are summarized in two. The first is that less developed countries (LDCs) need to build up their economy before turning to the ideals of democracy. Those following this consensus believe that the young democracy actually provides an obstacle to development rather than fueling it. The other side proposes that political freedom will actually help to breed economic growth, and that in the absence of too much governmental control over private industry, more robust economic outcomes will be realized.

Must political and economic growth be promoted in isolation of one from the other, or can it be that the presence of one leads to a greater victory for the other? A study at Illinois State University by Nelson and Singh (1998) gives credence to the idea that political and civil freedoms provided by the governments of developing countries lead to economic growth. Their empirical testing refutes the first premise and instead demonstrates positive links between democracy and economic growth. If this is the case then it can be asked that how much democracy raises the growth rate of an economy.

Barro (1996) limits this ability of raising growth to nations starting with lower levels of political freedom and actually diminishes growth when a moderate freedom is currently established. He also indicated that the positive affect of democracy on growth, even with these lower levels of freedom, is weak. Overall his study determined that a push toward political democracy is not the answer for these countries to improve their economic outlook.

A review of the effects of democracy on economic growth and inequality by Sirowy and Inkeles (1990) found little evidence to support the theory that democracy initiates economic growth. Based on the weakness of the methodology here, they concluded that it is probably stretching to say that the relationship does not exist. What then can be said about the link between political and economic democracy? It appears that the dispute raging for many years will continue. Others, using different methodology, have come up with an even greater variety of answers to this well debated question.

What transitional steps can non-democratic and/or partially democratic countries take toward social and economic prosperity? There is no easy prescription for the determinants of democracy or economic freedom. These determinants can be used and assessed to consider what actions developing nations can take to help ensure that their citizens enjoy the benefits of economic and social prosperity. The fact that there are certain determinants for democracy is not a question; the factors (variables) that are used, however, vary widely.

Johnson (1999) cites ten factors of economic freedom, some of which will be discussed here. He starts with trade policy, which is considered an important factor for economic freedom. According to Stiglitz and Charlton (2005), it is believed that no restrictions at all on foreign trade will be welfare enhancing for that country. Nelson and Singh (1998) found little significance that open trade was positively linked to economic growth; however, they do cite an explanation in how they constructed another variable tested which also included trade policy and this could account for the lack of significance. Democratic Transitions, by Epstein, Bates, Goldstone, Kristensen, and O'Halloran (2006) an article that challenges the fundamental idea of modernization theory that an increase in per capita GDP is not a factor of democracy, indicates that free trade helps full democracies, but not partial democracies or autocracies. This does not show that trade policy is absolutely not a factor of democracy. It does show us that trade policy is a factor that needs more consideration than just free trade or autarky, which we will consider more later in the research through such categories as no change, improvement, or decline in trade policies.

Taxation is also a consideration for economic prosperity according to Johnson (1999). He considers any form of taxation to be a hindrance to economic activity and heavy taxation can lead to a decline in economic growth. Other researchers Barro (1996), however, consider taxation in the government consumption or intervention category. When the government is in control of much of the labor market, this in turn makes it hard for an individual to freely express his/her views for fear of a backlash. Thus motivation to economic improvement is undermined. It is widely viewed that a large public sector has a negative affect on democratic development. Barro (1996) confirms this idea by showing a negative correlation between government spending and economic growth. In contrast, however, a study by Hadenius (1992) reports that there is no significant relation between the size of the public sector (including: GNP, public consumption, and percentage of publicly owned hospitals) and democracy. 
Foreign investment constitutes another factor. Investment from other countries into the economy of a developing nation provides for capital investment to expand the business sector of these economies. Thus more restrictions in this area lead to less capital inflow and a reduction in the growth of the business sector while, less restrictions would allow for more growth. Johnson (1999).

Other factors linked to democracy include the urbanization rate. Barro (1999) indicates a reason for this may be that the people in outlying areas are not able to organize as are those in the cities. Thus, countries with larger cities tend to look more to the rights of citizens, since the citizens in these large urban areas can get together and strike against the political leaders. There could be strong grounds that a move to larger cities is also a move away from an agrarian economy, which has been seen as a step in the direction of economic growth.

The aforementioned factors, among others to be reviewed here, would provide some hints that there is a wide variety of areas that less developed countries need to take into consideration when looking at how they can promote economic prosperity for their people.

The war on terrorism, Iran gaining nuclear capabilities, and the conflict between Israel and the Hezbollah, bring to mind the question, "what are the effects of democracy on violence?" The consensus varies on this subject as well. Many of the developing democracies around the world are immersed in as much conflict as those with autocracies. Does this mean that democracy actually encourages violence? Gartzke (2005) studied this topic and found that free markets actually breed peace. He concludes that it is not the idea of selflessness that most believe is the answer to global peace, but it may just be that the invisible force that guides markets is what in the end will lead us to this peace. He states: "Global markets offer an alternative to the revelatory mechanism of warfare, while prosperity makes some forms of aggression unprofitable." Gartzke (2005, p. 16). He also proposed that People's desires to improve their own lives, make them less likely to start a war with another nation that they are linked to economically. Thus, self interest (and not greed) may take us a long way toward peace.

An overall analysis of the literature may lead one to the idea that globalization, as a general principle, is good for the economies of less developed countries. It does not seem to be a question among researchers of whether more globalization is needed or not. Instead, however, it appears that the bigger picture is how to go about globalization. Stiglitz and Charlton (2006) indicate that one must carefully implement a plan for globalization. They contrast the growth of East Asia after World War II and that of Latin America in about the same time period. The differences in economic policies of the governments may have had an impact on the decidedly different outcomes. The Asian economies flourished through their industrialization policies. A look at Latin America shows policies away from comparative advantages.

The clear observation by Stiglitz and Charlton (2006) was that many of these countries thought that the industries in which they now had comparative advantage would not lead them into long-term growth. Thus, these countries turned to import substitution and their economies grew rapidly. Some of these countries ultimately ended up in a period of no growth during the 1980s. The view here is that trying to transition into areas in which they had little comparative advantage leads to too much government spending and ultimately high inflation. The problem here does not appear to be globalization, but how these different regions went about it.

Rodrik (1998) points out however that some of the other countries that used the import substitution strategies avoided the problems seen in the Latin American countries in the 1980s. He cites the example of India, which also used this type of strategy but did not experience the stagnation that Latin America did in the same period. $\mathrm{He}$ also comes up with a similar conclusion that it is not a question of if - but - how you go about globalization.

Both studies discuss the relative instability of the international market. Rodrik (1998) gives three strategies for reducing this risk. The first strategy includes getting rid of corruption in the judiciary and public bureaucracy. Next, he concludes that there is a need to give the working class more of a voice. He, therefore, indicates that a strong, widely-based trade union would be a good thing here. Finally, he cites the importance of providing safety from market risks. 
There is much to be gained from foreign trade if a country takes steps cautiously to implement its policy changes. Stiglitz and Charlton (2006) discussed these gains starting with comparative advantage from the ability of each country to specialize in what they can produce efficiently. More liberal trade policies allow a country to participate more in foreign markets, which broadens the demand for their domestic goods. Globalization can also reduce the costs associated with production, if the business sector is able to utilize the foreign market to get lower cost inputs. Competition from foreign markets can lead to more efficiency in the local economy. A liberal trade policy may ultimately lead to increased growth in the economy.

\section{AN EMPIRICAL ANALYSIS OF ECONOMIC FREEDOM}

Economic freedom is assessed and graded between 1 (best) - 5 (worst) by Heritage Foundation (2006 Index of Economic Freedom) through the following indicators:

International direct aid, trade policy (TABLE 1), fiscal burden, government intervention, monetary policy (TABLE 2) , capital flows \& foreign investment, banking and finance, wages \& prices, property rights (TABLE 3), regulation, and informal market.

\section{Figure 1}

Scores of Economic Freedom, EF (1-5)

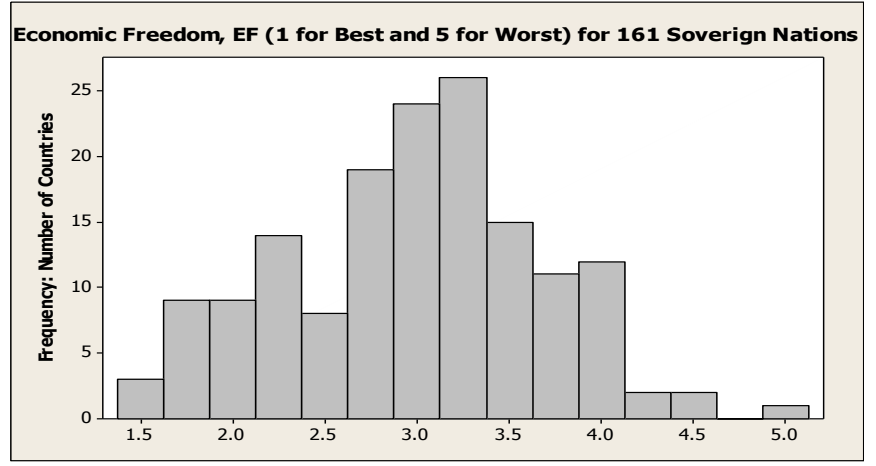

The above Figure shows the distribution of economic freedom scores along with the corresponding number of countries in each category. Also, to take just three examples, the following three tables exhibit the relevance of economic growth and prosperity for many nations of the world and various components of economic freedom (trade policy: Table 1, stable monetary policy: Table 2 , and property rights: Table 3 ).

Table 1

Free Trade and GDP per Capita for Many Nations with Various Trade Policies

\begin{tabular}{|c|c|}
\hline Trade Policy Change (1997 - 2006) & GDP per Capita Growth: 1995-2004 \\
\hline Improved & $2.5 \%$ \\
\hline No change & $2.1 \%$ \\
\hline Declined & $1.8 \%$ \\
\hline Trade Policy Change (1997 - 2006) & 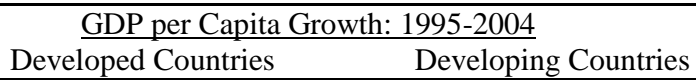 \\
\hline Improved & $2.6 \%(20$ countries $)$ \\
\hline No change & $2.2 \%$ (29 countries) \\
\hline Declined & $1.8 \%$ ( 25 countries $)$ \\
\hline
\end{tabular}

Source: The Road to Prosperity, the Heritage Foundation, 2006 
Table 2

Monetary Policy Stability \& Economic Prosperity

\begin{tabular}{|l|l|l|l|}
\hline $\begin{array}{l}\text { Monetary Policy Score } \\
\text { Change(1997 Index-2006 } \\
\text { Index) }\end{array}$ & $\begin{array}{l}\text { Average GDP per Capita } \\
\text { Growth (1995-2004 }\end{array}$ & $\begin{array}{l}\text { Monetary Policy Score } \\
\text { Change (1997 Index-2006 } \\
\text { Index) }\end{array}$ & $\begin{array}{l}\text { Average GDP per Capita } \\
\text { Growth (1995-2004 }\end{array}$ \\
\hline $\begin{array}{l}\text { Countries with largest } \\
\text { improvement }(+4)\end{array}$ & $4.0 \%$ & $\begin{array}{l}\text { Countries with largest decline } \\
(-2)\end{array}$ & $2.1 \%$ \\
\hline
\end{tabular}

Source: The Road to Prosperity, the Heritage Foundation, 2006

Table 3

Property Rights Variations versus GDP per Capita Growth

\begin{tabular}{|l|l|l|l|}
\hline $\begin{array}{l}\text { Property Rights Score } \\
\text { Change (1997 Index-2006 } \\
\text { Index) }\end{array}$ & $\begin{array}{l}\text { Average GDP per Capita } \\
\text { Growth (1995-2004 }\end{array}$ & $\begin{array}{l}\text { Property Rights Score } \\
\text { Change (1997 Index-2006 } \\
\text { Index) }\end{array}$ & $\begin{array}{l}\text { Average GDP per Capita } \\
\text { Growth (1995 - 2004 }\end{array}$ \\
\hline $\begin{array}{l}\text { Countries with largest } \\
\text { improvement (+2) }\end{array}$ & $2.0 \%$ & $\begin{array}{l}\text { Countries with largest decline } \\
(-2)\end{array}$ & $0.6 \%$ \\
\hline
\end{tabular}

Source: The Road to Prosperity, the Heritage Foundation, 2006

\section{REGRESSION ANALYSIS}

In this section, the authors have taken 155 countries of the world for which all the needed data were available, and examined the significance and partial impacts of political rights (PR), civil liberties (CL), and rule of law (ROL) on variations of economic freedom (EF).

Theoretically, it is expected the following regression equation to be true:

$E F=a_{0}+a_{1} P R+a_{2} C L-a_{3} R O L$

Where:

$\mathrm{a}_{\mathrm{i}} \quad=$ partial coefficients for $\mathrm{i}=1,2,3$

$\mathrm{EF}=$ Economic freedom, varying between 1 (best) to 5 (worst)

$\mathrm{PR} \quad=$ Political rights, varying between 1 (best) to 7 (worst)

$\mathrm{CL}=$ Civil liberties, varying between 1 (best) to 7 (worst)

$\mathrm{ROL}=$ Rule of law

Equation (1) is hypothesized based on the way we assign scores to each variable. EF, PR, and CL are scored lower for better records and higher for worse, whereas, in the case of ROL (rule of law), the higher scores signify better performances. The countries' records, though, on the relationship between PR and EF, show an indirect relationship. The reason is the inclusion of two explanatory variables CL and PR, which are highly correlated. TABLE 4 summarizes the aforementioned regression estimation results. 
Table 4

Regression Results

$\mathrm{EF}=3.75-0.116 \mathrm{PR}+0.169 \mathrm{CL}-0.107 \mathrm{ROL}$
\begin{tabular}{lcccc} 
Predictor & Coef & SE Coef & \multicolumn{1}{l}{$\mathrm{T}$} & P-Value \\
\hline Constant & 3.7452 & 0.3819 & 9.81 & 0.000 \\
PR & -0.11618 & 0.04990 & -2.33 & 0.021 \\
CL & 0.16863 & 0.07574 & 2.23 & 0.027 \\
ROL & -0.10655 & 0.02303 & -4.63 & 0.000
\end{tabular}

$\mathrm{S}=0.408165, \mathrm{R}-\mathrm{Sq}=66.2 \%, \mathrm{R}-\mathrm{Sq}(\mathrm{adj})=65.6 \%$

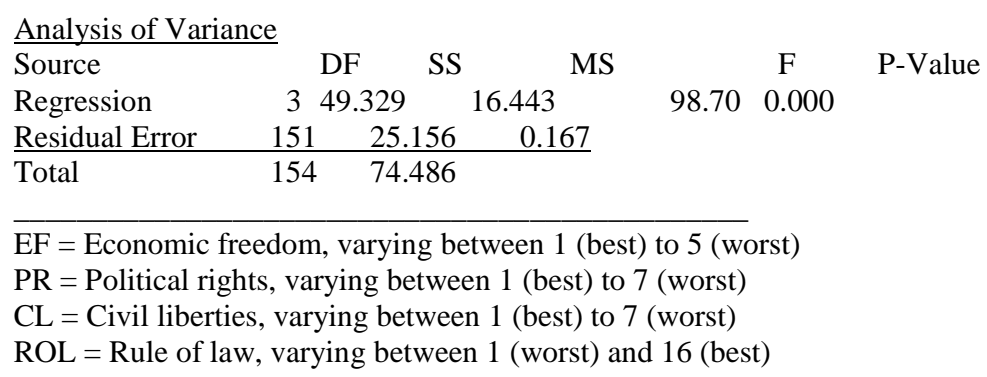

The relationship between EF and PR are expected to be theoretically positive. However, since there is a high correlation between PR and CL, on the one hand, and PR and ROL on the other, the results are suffered by multicollinearity. Other than that, the results are all statistically significant at better (lower) levels than 5\%. The goodness of fit is represented by a very high F-value, along with a zero corresponding p-value.

If we follow the House of Freedom's method and assuming that PR depends on many subcategories within political rights such as: Electoral process (A), political pluralism \& participation (B), and functioning of government $(\mathrm{C})$, then the following two equations would fit in the model:

$P R=f(A, B, C)$

$\mathrm{EF}=\mathrm{f}^{\prime}(\mathrm{PR})$

So, if we test regression (4), the following table will summarize the statistical results:

Table 5

Regression Results

$\mathrm{EF}(1-5)=2.21+0.232 \mathrm{PR}$

(5)

\begin{tabular}{|c|c|c|c|}
\hline Predictor & SE Coef & $\mathrm{T}$ & P-Value \\
\hline Constant & $2.20842 \quad 0.07242$ & 30.49 & 0.000 \\
\hline PR & 0.23183 & 12.79 & 0.000 \\
\hline
\end{tabular}

$\mathrm{S}=0.485090 \quad \mathrm{R}-\mathrm{Sq}=51.7 \% \quad \mathrm{R}-\mathrm{Sq}(\operatorname{adj})=51.3 \%$

Analysis of Variance

\begin{tabular}{llrrrl} 
Source & \multicolumn{1}{c}{ DF } & \multicolumn{1}{c}{ SS } & \multicolumn{1}{c}{ MS } & F & P-Value \\
Regression & 1 & 38.483 & 38.483 & 163.54 & 0.000 \\
Residual Error & 153 & 36.003 & 0.235 & & \\
Total & 154 & 74.486 & & &
\end{tabular}

$\mathrm{EF}=$ Economic freedom, varying between 1 (best) to 5 (worst)

$\mathrm{PR}=$ Political rights, varying between 1 (best) to 7 (worst) 
It is clear here with a high statistically significance that for every single score of improvement in political rights (PR), the economic freedom (FR) will be improved by 0.232 point. The same direct relationship is depicted in Figures (2-a) \& (2-b), as follows.

Figure 2-a

Economic Freedom, EF vs. Political

Rights, PR (1-7)

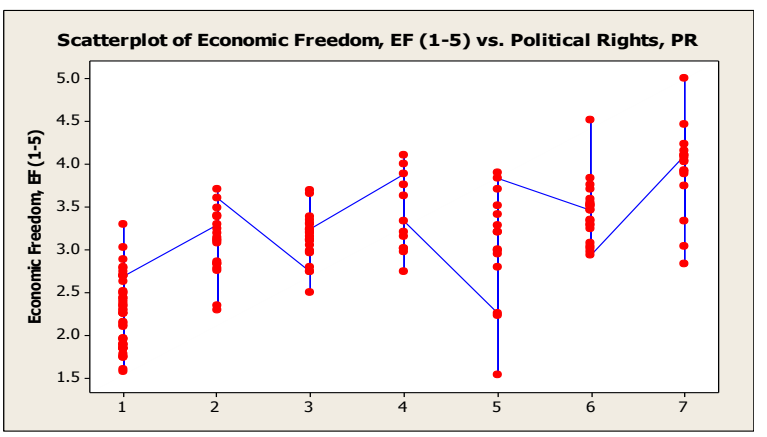

Figure 2-b

Economic Freedom (1-5) \& Political Rights (1-7) for 154 Countries

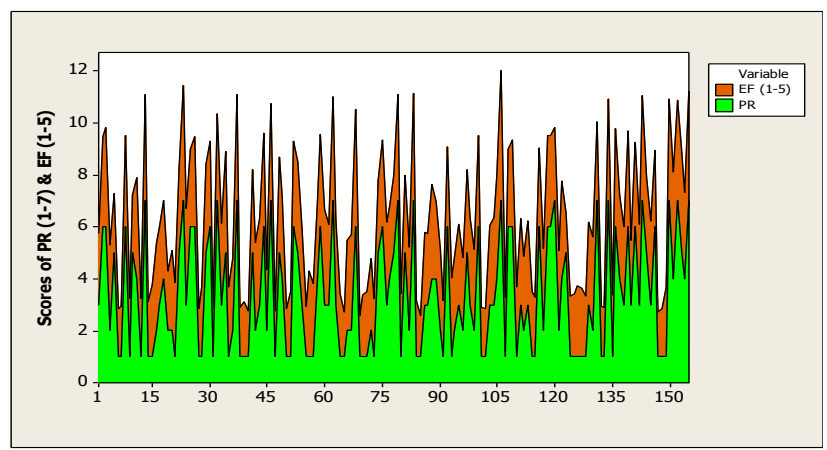

Records of political rights of the countries are exhibited in Figure 3, as follows. While there are many free countries with scores of 1 and 2, the number of those which are categorized in ranges of 5-7, signifying no or poor records of political freedom is still very high and worrying.

Figure 3

Number of Nations along with each score of Political Rights, PR (1-7)

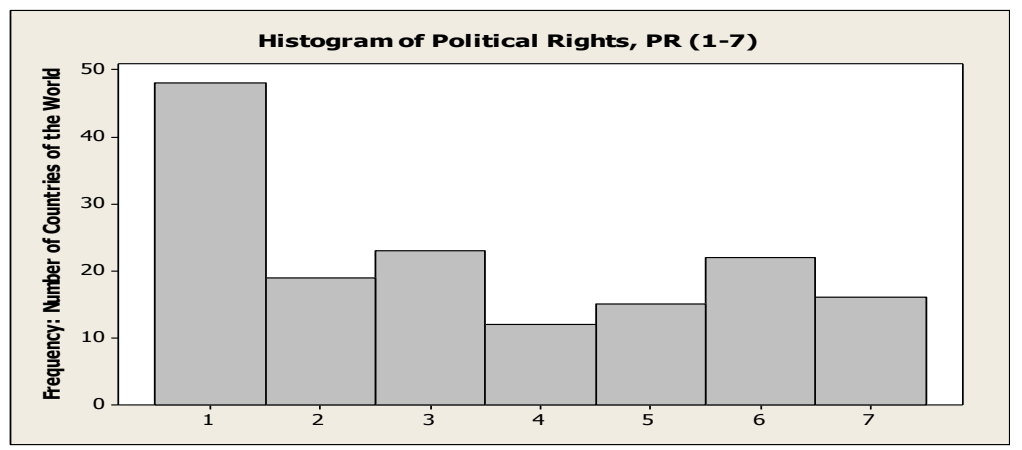

Furthermore, a different regression model, in which EF is explained by $\mathrm{C}$ (Functioning of the government) and $\mathrm{G}$ (personal autonomy \& individual rights) offers significant results, as clarified in TABLE 6 . These results imply that for every one point improvement in the records of government functioning, $\mathrm{C}$, and personal autonomy \& individual rights, $\mathrm{G}$, the economic freedom, EF, will be improved by .064 and 0.087 , respectively. 
Table 6

Regression Results

$\mathrm{EF}(1-5)=4.23-0.0640 \mathrm{C}-0.0865 \mathrm{G}$

(6)

\begin{tabular}{lllrl}
\hline Predictor & Coef & SE Coef & T & P-Value \\
Constant & 4.23243 & 0.09021 & 46.92 & 0.000 \\
C & -0.06397 & 0.02147 & -2.98 & 0.003 \\
G & -0.08650 & 0.02025 & -4.27 & 0.000 \\
& & & \\
S $=0.398840$ & R-Sq $=67.5 \%$ & R-Sq(adj $)=67.1 \%$ &
\end{tabular}

\begin{tabular}{|c|c|c|c|c|c|}
\hline \multicolumn{6}{|c|}{ Analysis of Variance } \\
\hline Source & & SS & MS & $\mathrm{F}$ & P-Value \\
\hline Regression & 2 & 50.307 & 25.153 & 158.12 & 0.000 \\
\hline Residual Error & 152 & 24.179 & 0.159 & & \\
\hline Total & 154 & 74.486 & & & \\
\hline
\end{tabular}

The estimation results in the following table represent a direct relation between civil liberties and economic freedom, where every point of improvement in countries' scores of civil rights has led to a 0.30-point improvement in their economic freedom achievement on the average. All statistical results are significant at all levels. Figures (4a) and (4-b) show the same linkage.

Figure 4-a

Economic Freedom (1-5) vs. Civil Liberties (1-7)

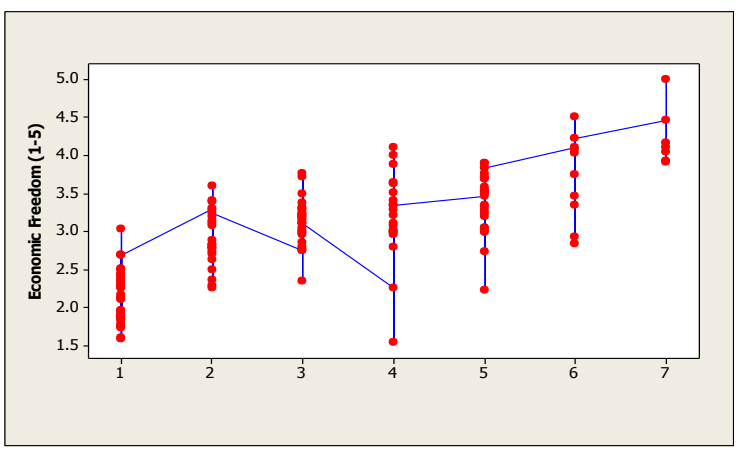

Figure 4-b

\section{EF (1-5) \& CL (1-7) for 154 Countries}

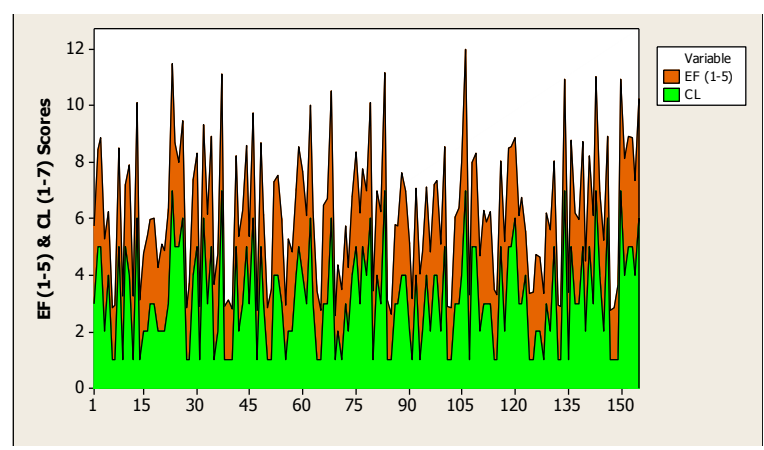


Table 7

Regression Results

$\mathrm{EF}(1-5)=2.03+0.301 \mathrm{CL}$

(7)

\begin{tabular}{|c|c|c|c|c|c|c|}
\hline Predictor & Coef & \multicolumn{2}{|c|}{ SE Coef } & $\mathrm{T}$ & \multicolumn{2}{|c|}{ P-Value } \\
\hline Constant & 2.02754 & \multicolumn{2}{|c|}{0.07149} & 28.36 & \multicolumn{2}{|c|}{0.000} \\
\hline CL & 0.30111 & \multicolumn{2}{|c|}{0.01951} & 15.43 & \multicolumn{2}{|c|}{0.000} \\
\hline$S=0.436366$ & \multicolumn{6}{|c|}{$\mathrm{R}-\mathrm{Sq}=60.9 \% \quad \mathrm{R}-\mathrm{Sq}(\mathrm{adj})=60.6 \%$} \\
\hline \multicolumn{7}{|c|}{ Analysis of Variance } \\
\hline Source & DF & SS & & MS & $\mathrm{F}$ & P-Value \\
\hline Regression & 1 & 45.352 & & 5.352 & 238.18 & 0.000 \\
\hline$\underline{\text { Residual Error }}$ & 153 & 29.133 & & 190 & & \\
\hline Total & 154 & 74.486 & & & & \\
\hline
\end{tabular}

The following table shows that political rights and civil liberties are quite significantly and directly related.

Table 8

Regression Results

$\mathrm{PR}=-0.265+1.14 \mathrm{CL}$

\begin{tabular}{|c|c|c|c|c|}
\hline Predictor & SE Coef & $\mathrm{T}$ & P-value & \\
\hline Constant & -0.26490 .1099 & -2.41 & 0.017 & \\
\hline $\mathrm{CL}$ & 1.13750 & 37.93 & 0.000 & \\
\hline$S=0.670775$ & \multicolumn{3}{|c|}{$\mathrm{R}-\mathrm{Sq}=90.4 \% \quad \mathrm{R}-\mathrm{Sq}(\mathrm{adj})=90.3 \%$} & \\
\hline \multicolumn{5}{|c|}{ Analysis of Variance } \\
\hline Source & DF & MS & $\mathrm{F}$ & P-Value \\
\hline Regression & 647.20 & 647.20 & 1438.41 & 0.000 \\
\hline Residual Error & 68.84 & 0.45 & & \\
\hline Total & 154 & .04 & & \\
\hline
\end{tabular}

$\mathrm{PR}=$ Political rights, varying between 1 (best) to 7 (worst)

$\mathrm{CL}=$ Civil liberties, varying between 1 (best) to 7 (worst) follows.

The frequencies of countries' records of civil liberties and rule of law are exhibited in Figures 5 and 6 , as 
Figure 5

Number of Countries within

Each Score of Civil Liberties, CL (1-7)

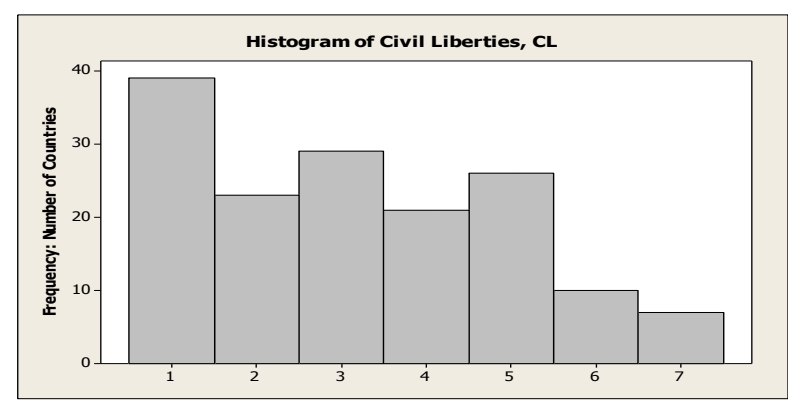

Figure 6

Number of Countries within Each Score of Rule of Law, ROL (1-16)

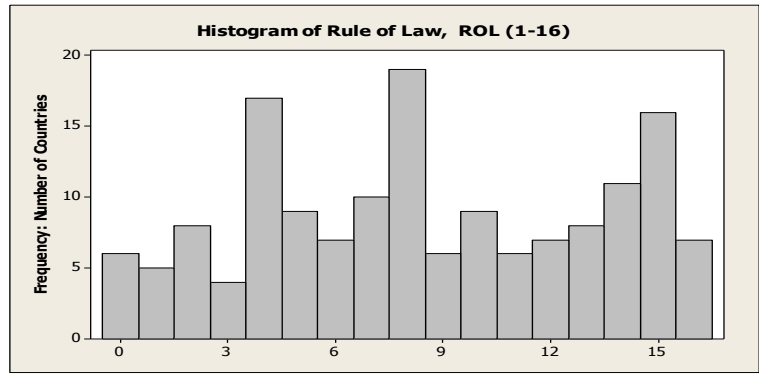

Considering the regressive rating of economic freedom ( 1 for best and 5 for worst), Figure 7 shows that economic freedom and rule of law are also directly related.

Figure 7

Economic Freedom, EF (1-5)

vs. Rule of Law, ROL (1-16)

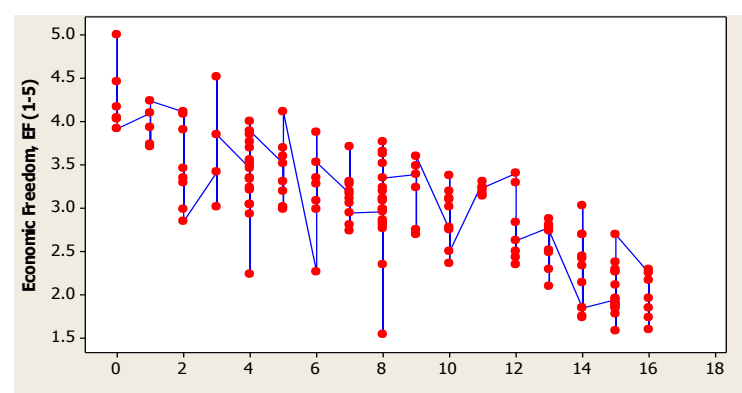

Figure 8

EF vs. PR, PR vs. CL, and EF vs. ROL (or F)

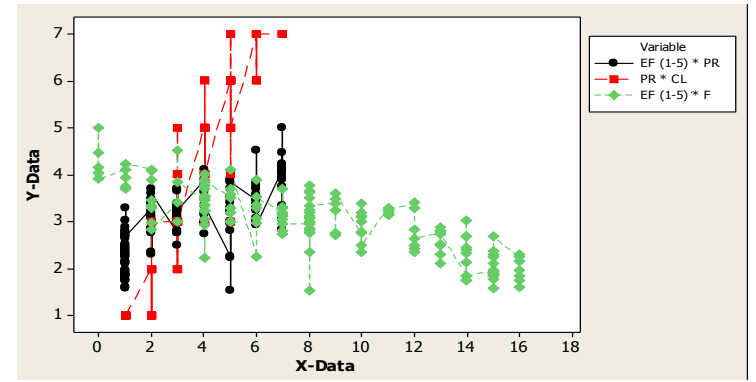

Figure 8 is a summarized graphical demonstration of three linkages: Economic freedom and political rights, political rights and civil liberties, and economic freedom and rule of law.

\section{CONCLUSION}

This study has offered an outlook to the current state of the global freedom. What is learned from other successful economies and businesses is the fact that freedom, in its general implications, is a real key to economic, social, civil, and political sustainable prosperity. In some empirical estimation, embodying 155 countries of the world, some tight as well as statistically significant relationships are detected among economic freedom, on the one hand, and civil liberties, political rights, and political freedom, on the other.

\section{BIBLIOGRAPHY}

1. $\quad$ Barro, R. J. 1996: Democracy and Growth. Journal of Economic Growth, 1(1): pp.1-27.

2. Barro, R. J. (1999). Determinants of Democracy. Journal of Political Economy, 107(6, part 2), S158-183.

3. Epstein, David L., Bates, Robert, Goldstone, Jack, Kristensen, Ida and O'Halloran, Sharyn. (2006). Democratic Transitions. American Journal of Political Science, 50(3): pp. 551-569.

4. $\quad$ Freedom House. (2006). Freedom in the World, [WWW document].

5. Gartzke, Erik. (December 2005). Capitalist peace or democratic peace? Institute of Public Affairs Review, Vol. 57, Issue 4, pp. 13-16. 
6. Hadenius, Axel. (1992). Democracy and Development, Cambridge University Press.

7. Heritage Foundation. (2006). 2006 Index of Economic Freedom. WWW.heritage.org.

8. http://hrw.org/english/docs/2006/05/03/nkorea13292 txt.htm

9. $\quad$ Iran Economics. (September 2006). Tehran, Iran.

10. Johnson, Bryan T. (1999). Methodology: Factors of the Index of Economic Freedom, in 1999 Index of Economic Freedom, The Heritage Foundation and Dow Jones \& Company, Inc., pp. 51-68.

11. Krugman, Paul R. and Obstfeld, Maurice. (2005). International Economics- Theory and Policy, 7th edition.

12. Nelson, Michael A. and Singh, Ram D. (1998). Democracy, Economic Freedom, Fiscal Policy, and Growth in LDCs: A Fresh Look, Economic Development and Cultural Change, 46(4): pp. 677-696.

13. Rodrik, Dani. (1998). "Globalization, Social Conflict and Economic Growth," World Economy, 21(2).

14. Rodrik, D., A. Subramanian, and F. Trebbi (2002). Institutions Rule: The Primacy of Institutions over Geography and Integration in Economic Development. NBER Working Papers No. 9305, URL: http://d.repec.org/n?u=RePEc:diw:diwwpp:dp310.

15. Sirowny, L., and Inkeles, A. (1990). "The Effects of Democracy on Economic Growth and Inequality: A Review.” Studies in Comparative International Development, 25(1), pp. 126-157.

16. Stiglitz, Joseph E. and Charlton, Andrew. (2006). Fair Trade for All, Oxford University Press.

17. The World Bank. (2002). World Development Report 2002: Building Institutions for Markets.

\section{NOTES}


NOTES 